\title{
Kurumsal İşlerin Analiziyle İşadamı Kavramının Betimlenmesi
}

\author{
Describing the Concept of Businessman Through Analyzing Institutional Works
}

\author{
Ozan AĞLARGÖZ1
}

\begin{abstract}
ÖZET
Bu çalışmanın amacı Türkiye bağlamında işadamı kavramının betimlenmesidir. Işadamı kavramı oldukça farklı anlamları içinde barındıran karmaşık bir kavramdır. Işadamı içinde bulunduğu kurumsal çevreyi etkilemekte ve aynı zamanda bu çevreden etkilenmektedir. İ̧adamı faaliyet gösterdiği kurumsal çevreyi yaratmak, sürdürmek ve yıkmak amacıyla çeşitli kurumsal işler yapmaktadır. Bu çalışmada işadamı kavramı işadamının yürüttüğü kurumsal işler aracılığıyla betimlenmektedir. Amaçlı olarak seçilen kurumsal bir biyografi aracılığıyla, bağlam bağımlı olarak, işadamının öncelikle genel kabul görmüş işadamı tanımını yıktığı, daha sonra işadamı kavramına ilişkin yeni bir anlam üretme çabasına giriştiği ve daha sonraki dönemde de işadamı kavramını sürdürme ve güçlendirme adına farklı kurumsal işleri yerine getirdiği belirlenmiştir.
\end{abstract}

Anahtar Kelimeler: Kurumsal iş, işadamı, kurumsal biyografi, kuram oluşturma.

\section{GíRiş}

Güncel Türkçe Sözlükte işadamı kavramı "kazanç sağlamak amacıyla ticaret veya sanayiye yatırım yapan kişi" olarak tanımlanıyor. Oxford'un İngilizce sözlüğünde ise "ticaretle, özellikle idari seviyede, uğraşan kişi şeklinde bir tanım verilmiş. Tanıma ek olarak verilen eş anlamlı sözcükler listesi ise oldukça uzun; bu listede girişimci kavramı da var, üretici kavramı da var, tedarikçi, tüccar, acente, dağıtımcı, depocu, perakendeci, müteahhit ve hatta kodaman diye bir kavram da var. Işadamı; her şey, ama belki de hiçbir şey!

Peki, kimdir bu işadamı, ne iş yapar, nasıl çalışır, neye önem verir? Bağlam denilen dipsiz kuyu işadamını nasıl etkiler? Bunlar ve benzeri sorulara cevap vermek için kullanılabilecek bir yaklaşım Sargut (2001)'den yola çıkarak kültürel değerlerin örgüt ve yönetim üzerindeki etkilerini ve bunun işadamı kavramına yansımalarını betimlemek şeklinde olabilir. Bir başka yol ise Buğra (2006)'da olduğu gibi işadamının faaliyet gösterdiği iş sistemi içindeki manevralarından bir anlam çıkartmaya çalışmaktır. Sargut (2001)'de ve

\begin{abstract}
The purpose of this study is to describe the concept of businessman in the context of Turkey. The concept of businessman covers various meanings and thus it is complex. Businessman shapes and is shaped by the institutional environment in which he operates. Businessman conducts institutional works in order to create, maintain and disrupt the institutional environment surrounding him. Businessman, in this study, is defined through the institutional works that he conducts. With the support of purposefully selected, context-dependent institutional biography, businessman primarily disrupt the taken-for-granted definition of the concept, conducts a meaning creation initiative for re-defining the concept and finally conducts various institutional works in order to maintain and enhance the created concept.
\end{abstract}

Keywords: Institutional work, businessman, institutional biography, grounded theory.

Buğra $(2006)^{2 \prime}$ da kısmen değinilen, fakat bütüncül bir yaklaşımla yeniden değerlendirildiğinde, işadamı kavramını betimleme potansiyeli olan bir başka yol ise işadamının faaliyet gösterdiği kurumlarla olan etkileşiminin analiz edilmesidir. Bu çalışma kapsamında işadamı kavramı giriştiği kurumsal işlerin (Lawrence ve Suddaby, 2006) analizi aracılığıyla betimlenecektir.

Çalışmada öncelikle yeni kurumsal kuram açısından kurumsal iş kavramına ilişkin kavramsal çerçevenin çizilmesine çalışılacak, daha sonra çalışma kapsamında tercih edilen yöntem yürütülen analizlerle ilişkilendirilerek açıklanacak, devam eden bölümde kurumsal işlerin kullanımı aracılığıyla işadamı kavramına yüklenen anlam betimlenecek ve çalışma ulaşılan sonuçlar ile daha sonraki çalışmalara yönelik önerilerin okuyucuyla paylaşılmasıyla son bulacaktır.

\section{KAVRAMSAL ÇERÇEVE}

Kurumsal kuram kapsamında yürütülen çalışmalardan çıkarılan genel sonuç kurumların aktörün davranışlarını yönlendirdiği şeklindedir (Meyer ve Rowan, 1977; Dimaggio ve Powell, 1983; Greenwood

${ }^{1}$ Yrd.Doç.Dr., Anadolu Üniversitesi, İktisadi ve İdari Bilimler Fakültesi, İşletme Bölümü, ozanaglargoz@anadolu.edu.tr 
ve Hinings, 1996). Kurumsal yaklaşım geleneği; genel olarak kurumsal koşullar sonucunda ortaya çıkan örgütsel benzerliklerin açıklanması konusuna odaklanmış olsa da, 90'lı yıllarla birlikte aktörün kurumlar ve kurumsal alan üzerindeki etkisi ile aktörün kurumları ve kurumsal alanı değiştirme kapasitesi konusuna ilişkin yeni bir araştırma akımının ortaya çıkarak, geliştiği belirtilmektedir (Lawrence ve Suddaby, 2006: 215).

Tarihsel bir değerlendirme yapıldığında, çağdaş (yeni) kurumsal kuram alanında bireyin neredeyse gözden kaybolduğu (Greenwood vd., 2008), fakat geleneksel kurumsalcılıkta birey ve kurum arasındaki etkileşimin (Örn. Berger ve Luckman, 1966) yadsınmadığı görülecektir. Kurumsal kuramın tarihsel gelişimi içerisinde kurumların yaratılması konusunda kurumsal girişimcilik (Eisenstadt, 1980; DiMaggio, 1988) kavramının önemli bir açıım sağladığı belirtilebilir. Ayrıca kurumların dönüşümü ve yıkımı (Oliver, 1992; Ahmadjian ve Robinson, 2001) gibi konularda da, yoğun olmamakla birlikte, filizlenen bir ilginin varlığından söz edilmektedir. Kurumların örgütsel eylemlere olan etkisini araştırmaya odaklanan kurumsal çalışmaların yanı sıra örgütsel ve bireysel aktörlerin eylemlerinin kurumlar üzerindeki etkisini anlamaya çalışan bir araştırma akımının da artan derecede önem kazandığı ve gelecekte kurumsal kuram kapsamında yürütülen çalışmaların önemli bir boyutunu oluşturacağı düşünülmektedir (Lawrence ve Suddaby, 2006: 216).

Günümüzde kurumsal kuram örgütleri anlama çabalarına yönelik baskın kuramsal yaklaşım olarak nitelendirilmektedir. Bu durum ilgili kurama ayrılan kongre zamanları ve akademik dergiler incelendiğinde açıkça görülecektir. Fakat kurumsal kuram kendi kuramsal baskınlığının altında ezilmekte ve yeni çıkış yolları aramaktadır. Kurumsal kuram kapsamında ele alınan kurumsallaşma, kurumsal değişim ve kurumsal mantıklar gibi alanın makrodinamiğini anlamaya odaklı konular büyük çaplı sosyal ve ekonomik değişimleri yorumlamaya odaklanmıştır. Böyle bir yaklaşımda örgütsel aktörlerin yaşanmışlıklarına ve bu yaşanmışlıklar aracılığıyla yapılan ve yapılandırılan kurumlara ilgi gösterilmemektedir. İşte kurumsal iş kavramı kurumsal paradigmayı içine düştüğü bu darboğazdan kurtarabilme potansiyeli olan bir kavram olarak karşımıza çıkmaktadır (Lawrence vd., 2011: 52).

Kurumsal iş kavramını net bir şekilde ortaya koyabilmek için kavramı bileşenlerine ayırarak incelemek yerinde bir eylem olarak görülmektedir. Kurumlar ve iş (çalışma - ing. work) konusu örgüt kuramları alanında yoğun bir şekilde fakat farklı açılardan ele alınmaktadır (Lawrence vd., 2013: 1023). Kurum kavramına ilişkin çeşitli tanımlar mevcuttur. Kurumsal iş yaklaşımında ise kurumlar; bireysel ve kolektif aktörlerin dav- ranış ve inanışlarını eylemsel, bilişsel ve duygusal açıdan çeşitli şablonlar sunarak şekillendiren (DiMaggio ve Powell, 1991; Meyer ve Rowan, 1977; Scott; 2008) ve bu şablonlara uyulmadığı durumlarda aktörün bazı maliyetlere katlanmak zorunda kaldığı (DiMaggio ve Powell, 1983; Jepperson, 1991) sosyal yaşamın süreklilik arz eden (Hughes, 1936'dan aktaran Lawrence ve Suddaby, 2006) bileşenleri şeklinde tanımlanmaktadır. Kurumsal iş kavramına ilişkin çalışmalarda çıkış noktası kurumlar değil işin kendisidir. İş kavramı bireysel veya kolektif aktörlerin sahip oldukları rolleri, ilişki kalıplarını, kaynakları ve rutinleri kendilerine sunan içinde yaşadıkları, çalıştıkları, eylemde bulundukları kurumsal yapılarla baş etmeleri, uyum sağlamaları; bu yapıları desteklemeleri, yıkmaları, düzeltmeye çalışmaları, dönüştürmeleri veya yeni kurumsal yapıların yaratılması yönündeki çabaları şeklinde düşünülmelidir (Lawrence vd., 2011: 53). İş kavramına ilişkin örgüt kuramları alanındaki yaklaşım oldukça karmaşıktır. Philips ve Lawrence (2012: 223) iş kavramına olan ilgiyi araştırma konusu yapmış ve örgüt kuramları alanında 15 farklı iş türünün var olduğunu saptamıştır. Erişilen tüm bu iş kavramlarının ortak noktası ise aktörün içinde bulunduğu bağlamı sosyal veya sembolik açıdan manipüle etme çabasını bünyelerinde barındırmalarıdır (Philips ve Lawrence, 2012: 224).

Kurumsal iş kavramı bireysel veya örgütsel aktörlerin kurumları yaratmak, sürdürmek ve yıkmak adına giriştikleri amaçlı eylemler şeklinde tanımlanmaktadır (Lawrence ve Suddaby, 2006: 215). Kavramın üç temel ayırt edici özelliği olduğu belirtilmektedir. Öncelikle kurumsal işi yapan aktör eylemlerinde düşünümsel, hedef odaklı ve yetkin bir şekilde hareket etmektedir, ikinci olarak kurumsal iş alanında aktörün eylemleri kurumsal dinamiğin odağında yer almaktadır ve son olarak kurumsal iş yapı, eyleyen ve bunlar arasındaki karşılıklı ilişkilerin anlaşılmasına aracılık etmektedir (Battilana ve D'Aunno, 2009).

Kurumsal iş kavramı araştırmacıları araştırma nesnelerini değiştirmeleri konusunda cesaretlendirmektedir. Bir başka deyişle, araştırmacıları örgütsel alanda yaşanan büyük çaplı sosyal dönüşümler yerine kurumlar ile kurumların içini dolduran aktörler arasındaki ilişkiyi daha yakından incelemeye odaklandırmaktadır (Lawrence vd., 2011: 57). Kurumsal iş kavramına ilişkin orijinal tanımda yer alan amaçlı eylemler ifadesi kurumsal işin yüksek düzeyde bilinçli bir niyetle girişilen iş olduğunu göstermek için kullanılmaktadır. Amaçsız bir şekilde girişilen işlerin de kurumsal düzeyde önemli etkileri olabilir fakat bu eylemleri kurumsal iş olarak değerlendirmek mümkün değildir (Lawrence vd., 2009: 11-13). 


\section{YÖNTEM VE ANALIZ}

Daha önce belirtildiği gibi kurumsal iş kavramı kurumsal kuram alanında çalışan araştırmacıları araştırma nesnelerini değiştirme konusunda cesaretlendirmektedir. Kurumsal iş kavramı bireyi kurumsallaşma sürecine uyum sağlayan bir aktör olarak nitelemek yerine motivasyonu, ilişkileri ve davranışları aracılığıyla kurumlar üzerinde doğrudan etkiye sahip bir eyleyen olarak nitelendirmektedir. Bu noktada kurumsal biyografi olarak adlandırılan kavram aktörün eylemlerini anlamak ve anlamlandırmak adına etkili bir açılım sağlayabilir. Kurumsal biyografi içeren çalışmalarda aktörün kendisini biçimlendiren kurumları yaratmak, sürdürmek veya yok etmek için giriştiği işler keşfedilmeye çalışılmaktadır (Lawrence, vd., 2011: 54-57).

$\mathrm{Bu}$ çalışmada, yürütülen kurumsal biyografi analizinin çalışmanın temel amacıyla uyumlu olması açısından, Glaser ve Strauss (1967) tarafından geliştirilen kuram oluşturma yaklaşımı çalışmanın araştırma yöntemi olarak benimsenmiştir. Tümevarımsal bir nitel araştırma yöntemi olarak kuram oluşturma nitel araştırma yaklaşımlarından en çok tercih edileni olmakla beraber, belki de, en çok sömürülenidir (Suddaby, 2006).

Kuram oluşturma yaklaşımı Glaser ve Strauss tarafından ortaya atıldığı şekilde kalmamış ve zaman içinde yaklaşımı ortaya atan iki yazarın yaklaşıma ilişkin "Strauss'un Yolu" ve "Glaser'ın Yolu" şeklinde farklılaşan görüşler ileri sürdükleri görülmüştür (Locke, 2001: 101; Myers, 2009: 109). Strauss ve Corbin (1990)'da öne sürülen görüşler yaklaşımın keşifsel yönünü törpülediği ve sınırlayıcılığı dolayısıyla eleştirilmektedir (Glaser, 1992). Bu çalışmanın yöntemsel duruş itibariyle Glaser (1992)'ye daha yakın olduğunu belirtmek yerinde olacaktır.

Araştırmanın temel amacı kurumsal biyografiler aracılığıyla işadamı kavramını betimlemektir. Bu amaçtan hareket ederek araştırmanın görgül materyalini oluşturacak kurumsal biyografi arayışına girilmiş (Patton, 2002: 230) ve bu arayış sonucunda Vehbi Koç (1901-1996)² tercih edilerek analiz sürecinde kullanılmıştır. Vehbi Koç tercihinin amaçlı olarak yapıldığı açıktır. Bu tercihin temel belirleyicisi Vehbi Koç'un kendisi tarafından kaleme alınan biyografilerin (otobiyografilerin) yayınlanmış olması (Koç, 1973; 1987), ayrıca bu eserlerin Can Dündar tarafından yeniden gözden geçirilerek (Dündar, 2006; 2008) tekrar yayınlanmış olması ve Vehbi Koç'u anlatan iş arkadaşları tarafından kaleme alınmış (Kıraç, 1996) eserlerin varlığıdır. Oldukça zengin sayılabilecek görgül metaryelin varlığının ve erişim kolaylığının yanında, Koç Grubu'nun çeşitlenmiş sektörel dağılımı ile Vehbi Koç'un Müslüman ve Türk kökenli bir işadamı olarak 1901-1996 yılları arasında yaşamış olması da çalışma kapsamında tercih edilişini destekleyen faktörler arasında sayılabilir. Müslüman ve Türk geçmişine sıklıkla vurgu yapan Vehbi Koç'un işadamı kavramını kurumsal işler aracılığıyla yapılandırdığını düşündüğümüz dönemlerde işadamı kavramı vergi kaçakçılığıyla özdeşleştirilmekte (Uras ve Berker, 2009: 21), girişimcilik ise horlanmakta, aşağılanmakta ve hiçbir saygın Türk vatandaşının girmeyeceği bir alan olarak nitelendirilmektedir (Buğra, 2006: 19). Böyle bir ortamda birçok işadamının değişik konularda Vehbi Koç'u ve Koç grubunu örnek aldığı (Buğra 2006: 262) göz önünde bulundurulduğunda çalışma kapsamında yapılan amaçlı seçimin oldukça yerinde olduğu belirtilebilir.

Çalışmanın görgül materyalinin omurgasını Vehbi Koç tarafından kaleme alınan Hayat Hikâyem başlıklı eser teşkil etmektedir. Kuram oluşturma yaklaşımı jargonuyla belirtmek gerekirse Hayat Hikâyem çalışmanın kuramsal olarak örneklenmiş görgül materyalidir (Locke, 2001: 55). Çalışma kapsamında bu eser genel olarak, Emirbayer ve Mische (1998)'in deyimiyle izdüşümsel eyleyen işlevi görmektedir. Diğer kaynaklar ise (Koç, 1987; Kıraç, 1996; Dündar, 2006; Dündar, 2008) Koç (1973)'de değinilen kurumsal işlere ilişkin bilgilerin nirengilenmesi amacıyla kullanılmıştır.

Çalışmanın analiz sürecine Länsisalmi vd., (2004: 246)'nin kuram oluşturma yaklaşımına dayalı araştırmalar için önerdikleri şablon rehberlik etmektedir. Analiz sürecinde öncelikle Hayat Hikâyem başlıklı eserde yer alan kurumsal işler tanımlanmıştır. Eser kapsamında toplam 452 adet işadamı kavramını yapılandırma amaçlı kurumsal iş olarak nitelendirilebilecek eylem, söylem veya imaya erişilmiştir. Daha sonra kuram oluşturma yaklaşımının temel çıkış noktası olan açık kodlama sürecine geçilmiş ve 452 eylemin içeriği analiz edilerek 82 koda ulaşılmıştır. 82 kod aracılığıyla kurumların yaratılması, sürdürülmesi ve yıkılmasına ilişkin eylemler betimlenerek, işadamı kavramının keşifsel çerçevesinin çizilmesi sağlanmıştır.

\section{BULGULAR VE YORUM}

Analiz sonuçları kuram oluşturma yaklaşımıyla irdelendiğinde Vehbi Koç'un işadamı kavramını yapılandırmak adına yıkım, yaratım ve sürdürme şeklinde özetlenebilecek bir sürecin (Locke, 2001: 109) içinde yer aldığı görülmektedir. Hayat Hikâyem üzerinde yürütülen analiz sonucunda Vehbi Koç'un öncelikle Türkiye'de var olan işadamı kavramını yıkma yönünde kurumsal işlere giriştiği, daha sonra yeni bir işadamı kavramı yapılandırmaya çabaladığı ve yapılandırdığı 
işadamı kavramına süreklilik kazandırmak amacıyla başka kurumsal işlere başvurduğu belirlenmiştir. Devam eden alt başlıklarda Vehbi Koç'un bakış açısıyla ve doğrudan alıntılarla Türkiye'de işadamı olmanın ne anlama geldiği betimlenmeye çalışılacaktır.

\section{1. İşadamı Algısında Gayrimüslim Tekelinin Yıkılması}

İşadamı kavramının yapılandırılmasında Koç'un giriştiği kurumsal işleri analiz ettiğimizde, bu sürecin öncelikle bir yıkım süreciyle başladığı açık bir şekilde görülmektedir. Koç erken gençlik dönemlerinde Ankara'nın bütün ticaretinin Ermeni, Rum ve Musevilerin elinde olduğunu belirtmekte ve Müslüman Türkleri ülkenin sahibi olmalarına rağmen çoğunlukla bu üç zümrenin emrinde çalışan ve basit hayatlar süren kimseler olarak betimlemektedir. Koç anılarında Müslümanların ve Gayrimüslimlerin servetlerine ilişkin karşılaştırmalar yapmakta ve aradaki, gayrimüslimler lehine, oluşan farka dikkat çekmektedir. Yapılan işler açısından Türklerin özel bir uzmanlık bilgisinden yoksun olduklarını, yaptıkları tek işin bakkallıktan ibaret olduğunu belirtmektedir. Bu durum mistik kökenli işgörme anlayışının bir sonucu olarak nitelendirilebilir (Aldemir vd., 2003: 23).

Koç esnaflık döneminde iş bilmezlikten dolayı çoğu kez gülünç duruma düştüklerini, bu durumun işleri büyüdüğünde de devam ettiğini belirtmektedir. Koç'a göre yapılması gereken ilk iş, işadamlığına ilişkin temel varsayımların ve inançların unutturulmasıdır. "Eşek kötü olduğu için bütün Hristiyan çocukları yolda kendi eşekleriyle beni geçerlerdi. Eşeğe babamın atının arpasından çalar yedirirdim. Kulaklarını dikmez, canlılık göstermezdi. Kısaca, tam o sıralarda esnaf olmayı kararlaştırdım. Eğer Allah bana 50.000 liralık bir servet verirse, Ankara'da beş katlı güzel bir mağaza açacağım diye kendime söz verdim. Okumamayı kararlaştırdım" (Koç, 1973: 15).

\section{2. İşadamı Kavramının Yaratılması}

\section{2. 1. Gayrimüslimlerle Benzeşim}

Koç anılarının birçok yerinde babasını risk almaktan kaçınan ve genellikle kira gelirleriyle geçinme hevesinde olan birisi olarak tanımlamaktadır. Babasının güvenini kazandıktan sonra gelişme, çeşitlenme ve intikam arzusuyla çevresindeki iş fırsatlarını gözlemlemeye başladığını belirtmektedir. "Ankara'daki işlerimiz zamanla bakkaliyeden hırdavata, hırdavattan köseleciliğe, köselecilikten yapı malzemesine çevrilince, bizim işlerin de bir kısmı Galata'ya aktarma olmaya başladı" (Koç, 1973, 25).

Her ne kadar işadamlığı kavramının inşası süreci gayrimüslimlerden intikam alma çabası olarak or- taya çıksa da, Koç'un hemen hemen tüm iş girişimlerinde işi bilen bir gayrimüslimle ortaklığa gittiği görülmektedir. Bu durum Türk işgörme tutumunda yaygın olduğu belirtilen riya anlayışından (Aldemir vd., 2003: 24) korunmak amacıyla girişilen bir eylem olarak düşünülebileceği gibi, aktörün yeni kurumsal kural, teknoloji ve uygulamalara uyumu kolaylaştırmak amacıyla daha önceden var olan, yoğun bir şekilde kabul görmüş kural, teknoloji ve uygulamalarla bağdaştırma yoluna gitmesi şeklinde de yorumlanabilir. Bir başka deyişle, Koç iş kurarken ve çeşitlendirirken sürekli olarak gayrimüslimlerle benzeşim çabası içine girmektedir. "Çarşıda Rum, Ermeni, Musevi komşularımız vardı. Bu komşuların ne gibi işler tuttuklarını inceledim" (Koç, 1973: 26). Ebeoğullarının yanında Kosti adında iyi bir satıcı vardı. Bu satıcıyı almayı kafaya koydum, uğraştım, fazla para teklif ettim ve almayı başardım... Kosti bana bu meslekte çok şey öğretti, bu işte benim hocam oldu. Illk satıcım Bay Kosti'nin benim iş hayatımda büyük yeri vardır" (Koç, 1973: 26).

Alanında uzman ve teknik bilgisi kuvvetli kişilerden yararlanma daha sonraki dönemlerde girişilen işlerde de önemli bir ilke olarak kabul edilmekte, esnaflıktan tüccarlığa, tüccarlıktan sanayiciliğe geçişte uzmanlık bilgisi artık bireylerden değil de ortaklık kurulan yabancı işletmelerden elde edilmeye çalışılmaktadır. "Siemens acentalığı, Siemens ile ortak olarak 1959 yılında ortak olarak kurduğumuz Simko şirketine devredildi....Bütün istek ve hedefim, Siemens'in Türkiye'ye yatırım yapmasıydı. Yatırım yaparlarsa, Türkiye ile ve bizlerle ilişkilerinin kolay kolay kesilmeyeceğine inanıyordum" (Koç, 1973: 94).

\section{2. 2. İşadamı: Hizmet Adamı}

Türkiye'de amaçları ülke çıkarlarıyla uyumlu olan örgütlerin gelişeceği ve işadamının sosyal statüsünün ancak bu şekilde güçlenebileceği belirtilmektedir (Buğra, 2006: 348-349). Giriş bölümünde değinildiği üzere işadamı kavramına ilişkin tanımların farklıığı ve tanımların içinde yer alan kavramların çokluğu kavramın tam olarak anlaşılmasını zorlaştırmaktadır. Fakat tanımlarda hiçbir zaman işadamlığının vatana hizmet etmek şeklinde tarif edildiği görülmemektedir. Koç da bu durumun ve yarattığı çelişkinin farkındadır. Genişleyen ve gelişen işlerini sekteye uğratmamak ve işadamlığını daha sempatik bir kavram olarak yeniden konumlandırmak istemektedir. Bu nedenle işadamı kavramına ilişkin normatif çağrışımları yeniden tanımlama gayretine girmiştir. Bu iş uygulamaların altında yatan ahlaki ve kültürel temellerin yeniden formüle edilmesidir. Bu tür işler genelde var olan kuruma paralel veya tamamlayıcı bir başka kurumun ortaya çıkması ve var olan kurumun varlığının sorgulanması sonucunu doğurur (Lawrence ve Suddaby, 2006: 223- 
225). "Iş̧e bu koşullar altında, bu yollardan mal getirir, hem ordunun hem halkın ihtiyacını karşılardık" " (Koç, 1973: 32). "Koç Topluluğu şirketlerinin çoğu yurt ekonomisine katkısı olan, ülke yönünden verimli ve yararlı şirketlerdi. Bunların yaşaması ve gelişmesi gerekliydi" (Koç, 1973: 100).

\subsection{3. İşadamının Yol Haritası}

Koç'un anılarını bir bütün olarak ele aldığımızda işadamına ilişkin belli bir gelişim rotası çizdiğini görmekteyiz. Bu rota sosyal ve kültürel temeller dolayısıyla öncelikle bakkallıktan başlamaktadır. Bakkallıktan sonraki aşama komisyonculuktur. Komisyonculukta daha az risk fakat kitlesel satış söz konusu olmaktadır. Komisyonculuğun sağladığı getiriler işadamını eksiltmeciliğe doğru yöneltmektedir. Eksiltmecilik aslında işadamının rotasının devlet kurumuyla kesiştiği nokta olarak düşünülmelidir. Eksiltmecilik işinde hem komisyonculuk gibi belli ürünlerin ihale karşılığında kamu kurumlarına satışı söz konusu olmakta hem de inşaat-taahhüt işlerine girişilmektedir. Koç'a göre ancak eksiltmecilik sürecini başarıyla tamamlayan işadamı üretime geçiş yönünde girişimlerde bulunabilir. Bu yaklaşım Türkiye'de burjuvazinin sanayiciliği uzun süre ikinci sınıf iş olarak kabul ettiği ve önceliği girişim gerektirmeyen ve kolay para kazandıran konut yapımı, arsa spekülasyonları vbg. işlere verdiği şeklindeki görüşle örtüşmektedir (Cem, 2014: 385)4.

Koç'a göre üretim işi daha çok müşterisi hazır olan ve hammadde temininde sorun yaşanma riski düşük alanlarda yürütülmelidir. İşadamının mal üretiminin yanında hizmet üretimini de değerlendirmesi gerektiğine inanan Koç'a göre, ilk açılım yapılması gereken hizmet işi turizm işidir. İ̧̧adamı bu işlerin tümünü aynı anda sürdürebilir veya işleri geliştikçe ana faaliyet konusu dışında kalan işleri tasfiye edebilir. Fakat bırakmaması gereken yegâne iş mağazacılıktır. Bu tutum belki de işe bakkal olarak başlamanın önemli bir tarihsel sonucudur. Koç'a göre bir şeyi satmak en azyapmak kadar önemlidir. Ayrıca Türkiye'de işadamının çıkış noktası neresi olursa olsun hedefi İstanbul olmalıdır. "Ankara bana ufak gelmeğe başladı, bütün hevesim Istanbul'da bir mağaza açmaktı." (Koç, 1973: 40). "Üç ay daha Çankırı'da kaldık. Bu sürede boş durmadım. Çankırı piyasasını inceledim. Çankırı'da hırdavat işiyle uğraşan Poşyan'lardan kâğıt, zarf ve diğer hırdavat eşyası alarak Ankara'ya göndermeğe başladım" (Koç, 1973: 29). "Geseryanlar bu büyük binada Sahibinin Sesi gramafon plaklarını, Philco radyolarını, Kelvinatör buz dolaplarını satıyorlardı. Birkaç konuşmadan sonra biz bu firmanın Ankara satıcısı olduk"(Koç, 1973: 35).

\section{2. 4. Tecrübelerden Öğrenme}

Türk kültürünün yaygın özellikleri olarak nitelenen düşük sinerji, düşük güven ve geniş bağlamlılık (Sargut, 2001: 140-150) öğrenme konusunda Koç'u yönlendiren etkenler arasında sıralanabilir. Bu tür kültürel bağlamlarda toplum dar, küçük ve çok sayıda iç gruba bölünme eğilimdedir (Sargut, 2001: 143), bu durum bireyi yakın çevresindekilerin tecrübelerinden öğrenmeye ve/veya yakın çevresini öğretme potansiyeli olan tecrübeli kişilerle donatmaya yöneltmektedir.

Koç'a göre işadamının en temel ayırt edici özelliği sürekli öğrenme isteğidir. İşadamlarının en önemli öğrenme kaynakları başkalarının tecrübeleri ve iş gezileridir. Tecrübelerden öğrenme konusunda öncelikle alanında uzman bireyleri işe alma veya işe ortak etme iyi bir alternatif olabilir. Bunun dışında işadamının iyi bir gözlem yeteneği de olmalıdır. Biçimsel eğitim ve yabancı dil bilgisi de Koç'un üzerinde yoğun bir şekilde durduğu eğitimle ilgili konular arasında yer almaktadır. "Hayatta başarılı olmanın sırları arasında belki de en önemlisinin başkalarının tecrübelerinden yararlanmak, verilen ögütleri can kulağı ile dinlemek, ilgili yayınları dikkatle okumak ve kazanılan bilgileri değerlendirmek olduğuna inanıyorum (Koç, 1973 Önsöz). Biraz tanındıktan, biraz para kazandıktan sonra daha ilerleyebilmek için Avrupa'ya gitmek hevesine düştüm" (Koç, 1973: 59).

\section{2. 5 İsimlendirme}

Kurumsal işler arasında kuramlaştırma da Koç tarafından işadamı kimliğinin ortaya çıkarılmasında girişilen önemli bir çaba olarak karşımıza çıkmaktadır. Soyut kategorilerin geliştirilmesi, özelliklerinin betimlenmesi ve kategoriler arasındaki neden sonuç ilişkilerinin açıklığa kavuşturulması şeklinde tanımladığımız kuramlaştırma çabalarının en somut uygulaması isimlendirmedir (Lawrence ve Suddaby, 2006: 225229). "Sıkışık duruma düşmüşler, bana ortaklık teklif ettiler...Ş̧irketin adı "Koç - Boru" olması şartıyla ortaklığı kabul ettim" (Koç, 1973: 36). "Böylece Koçzade Ahmet Vehbi Firması kurulmuş oldu" (Koç, 1973: 40). "1937 yılında Istanbul şubemizi "Vehbi Koç ve Ortakları Kollektif Şirketi" adıyla Fermenciler'de kurduk...\%15 hissesi İsrail Efendinin, \%15 Hissesi Emin Bey'in ve \%70 Hissesi de benimdi" (Koç, 1973 41). "Galata Grubumuz Koç Ticaret A.Ş.'nin Galata şubesi oldu" (Koç, 1973: 44).

İsimlendirme işi temel olarak örgütsel kimliğin dışavurumu şeklinde ifade edilmektedir (Glynn ve Abzug, 2002: 267). İlgili literatür incelendiğinde örgütsel kimliğin işlevine ilişkin iki yaklaşımın varlığına rastlanmaktadır. Bunlardan ilki örgütsel kimliği 
örgütün temel, süregelen ve onu diğer örgütlerden farklılaştıran özellikler bütünü olarak betimlemektedir (Albert ve Whetten, 1985). Diğer yaklaşım ise örgütsel kimliğin belli bir sınıfa ait olmanın göstergesi olduğunu ileri sürmektedir (Ashfort ve Gibbs, 1990: 181). Vehbi Koç'un, örnek alıntılarda görüldüğü gibi, "Koç" bağlantılı isimlendirme çabaları, O'nun bu yolla hem özel (işadamı olarak) hem de tüzel (işletme olarak) varlığını duyurma ve aslında güçlü bir markalama uğraşına giriştiği şeklinde yorumlanabilir. Bir başka ifadeyle, Koç isimlendirme işinde Albert ve Whetten (1985)'nın örgütsel kimlik yaklaşımını benimsemiştir. Koç sonrası dönemde ise isimlendirme işi daha çok Ashfort ve Gibbs (1990)'in yaklaşımıyla uygulanmaya çalışılmış (Bkz. Buğra, 2006: 89; Çolpan ve Hikini, 2008: $30-32$ ) ve isimlendirme sembolik eşbiçimlilik (Glynn ve Abzug, 2002: 267) aracılığılla meşruiyetin kaynağı olma işlevini üstlenmiştir.

\section{3. İşadamlığının Sürdürülmesi}

\section{3. 1. Çeşitlenme}

Türkiye'de yerleşik işletme gruplarında işlerin ilişkisiz bir şekilde çeşitlenmesi geç-sanayileşmenin bir sonucu olarak değerlendirilmektedir (Gökşen ve Üsdiken, 2001: 328). İşadamlığının sürdürülmesi aslında işlerin sürdürülmesidir. Bu noktada Koç'un başlangıç noktasından itibaren işleri büyütürken, çeşitlendirme isteğinin de olduğu görülmektedir. İşlerin çeşitlendirilmesinde herhangi bir kalıbın varlığına rastlanamamıştır. Koç'a göre çeşitlendirme işadamının iş yaptığı sektörel çevrenin bir sonucu olarak değerlendirilmelidir. Bu açıdan işadamı sektörel çevredeki değişimleri yakından takip ederek fırsatları değerlendiren kişi olarak tanımlanmaktadır. "Atatürk'ün Ankara'yı başkent yapması şehre büyük bir canlılık getirdi. Bayındırlık ve yapı işleri başladı. Ben de bakkaliye, köselecilik ve hırdavat işlerini bıraktım, yapı malzemesi işine girdim" (Koç, 1973: 48).

Koç örneği çeşitlenme konusunda herhangi bir kalıp ortaya koymuyor olsa da, işler genişletilirken genelde geriye doğru dikey bütünleşme çabasının varlığı göze çarpmaktadır. İşadamlığının ilk yıllarında Koç hammaddeye yaklaştıkça riskin azalacağını ve gelirin artacağını düşünmektedir. Bu durum, belki ilk bakışta doğru gibi kabul edilse de, geri ve ileri yönlü bütünleşmenin doğru bileşiminin işe, işletmeye ve sektöre bağlı olarak farklılık göstereceği oldukça açıktır. Koç'un önceleri hammaddeye yaklaşarak kârlılık düzeyini artırmak hevesinde olduğu, fakat daha sonraki dönemde hammadde tedarikinin yanında satış potansiyelini de garanti altına alarak üretim işini daha kârlı kılan oldukça bütünleşik bir yapıyı tercih ettiği görülmektedir. "Kösele işinde en kuvvetli iki rakip bun- lardı. Bu meslekte eski ve tecrübeli insanlardı. Kösele işi bakkaliyeden çok daha iyi bir işti. Bozulması, modasının geçmesi yoktu. Kösele ve deri altınsa, ayakkabı olduktan sonra gümüş, belki de bakır kadar değeri kalıyordu" (Koç, 1973: 26). "Memleket çok güzel bir fabrika kazandı, iş gücü yarattı, büyük döviz tasarrufu sağlandı. Bugün buzdolabı ve ocaklar, tüpler bu fabrikanın mamulleri ile yapılmaktadır" (Koç, 1973: 111).

Buğra (2006: 189-190) çeşitlenme konusunu iş ortamının istikrarsızlığı ve genel olarak uzun dönemli stratejik planlama kültürünün yerleşmemiş olmasına bağlamaktadır. Bu durum işadamlarını kısa dönemde yüksek getiri elde edilebilecek işlere yönelme yönünde motive etmektedir. İşletme grupları üzerinde yürütülen çalışmalar, Türkiye ekonomisinde 1980 sonrası yaşanan liberalleşme akımına rağmen işadamlarının işlerini çeşitlendirerek büyüme eğiliminde olduğu gerçeğini destekler niteliktedir (Gökşen ve Üsdiken, 2001:337). Çeşitlendirme eğiliminin dönemsel ayırım (1980 öncesi ve sonrası) olmaksızın devam ettiği fakat 1980 öncesi kurulan işletme gruplarında çeşitlenmenin daha çok imalat sektöründe yoğunlaştığı belirlenmiştir (Çolpan ve Hikino, 2008: 49).

\section{3. 2. Siyasetle Gevşek-Sıkı Illişkiler}

Türkiye iş sistemi devlete bağımlı (Whitley, 2000), devletin büyük iş gruplarını borç-alacak ilişkileri aracılığıyla denetlediği ve eşgüdümlediği (Gökşen ve Üsdiken, 2001:332) bir yapı olarak düşünülebilir (Berkman ve Özen, 2007: 3). Buğra (2006: 238)'ya göre Türkiye iş dünyasında başarılı olmanın yolu politik ve bürokratik süreçleri istendik yönde manipüle etmekten geçmektedir. İşadamının ortaya çıkışında siyasetle en önemli kesişim noktası, daha önce sözü edilen, eksiltmeler hususundadır. Bu seviyeden sonra işadamının siyasetle oldukça sıkı fakat aynı zamanda da bir o kadar gevşek ilişkiler içinde olması gerekmektedir. Siyasetle ilişkilerin sıkı olmasının temel sebebi devletin en büyük müşteri olmasından kaynaklanmaktadır. Sıkı ilişkileri canlı tutan bir başka neden devletin yetiştirdiği insan kaynaklarının özel sektörün ilk uzman işgücü kadrosunu oluşturmuş olmasıdır. Ayrıca devlet çeşitli ihaleler aracılığıyla bazı işadamlarını geliştirme bazılarını ise zorlama konusunda oldukça aktif bir rol oynamaktadır. Koç'un anılarında siyasetle olan ilişkiler önemli bir yer tutmaktadır. Koç'a göre düzenleyicileri/düzenlemeleri düzenlemek işadamı olmanın temel bir gerekliliğidir. Koç siyaset kurumuyla tanışmasını tarihsel gelişimin doğal bir sonucu olarak nitelendirmekte ve bunun reissen yapılmış bir seçim olduğunu sürekli vurgulamaktadır. "29 Ekim 1919 günü Reis Müfit Rıfat Efendi'nin Başkanlığı'nda Ankara'da kurulan Müdafaa-i Hukuk-u Milliye Cemiyetine babam da girmişti. O günkü koşullarda duruma göre 3000 kuruş 
maddi yardım da yapmış. Büyüklerimin isteği ile ben de 19 yaşımda bu Cemiyete girdim. Müdafaa-i Hukuk Cemiyeti sonradan Cumhuriyet Halk Partisi oldu. Ben de bu yoldan CHP'li oldum" (Koç, 1973: 133).

$\mathrm{Bu}$ tür bir vurgunun sebebi ise anıların ilerleyen bölümlerinde ortaya konan çeşitli olaylar aracilığıyla açıklanmaktadır. Demokrat Parti dönemi (1950-1960) aslında işadamının siyaset kurumuyla olan ilişkisinde idealin betimlendiği ve günümüzde de yansımalarını gördüğümüz bir ikna sürecidir. Koç CHP'de çeşitli görevler aldığını yadsımamakta fakat bu işlerin aktif politikayla ilgisi olmadığını, sadece kendi alanında danışmanlık hizmetleri verdiğini belirtmektedir. Çok partili dönemin her iki partisine de maddi yardım yaptığını gizlememekte, hatta gerekirse yine yapacağını belirtmektedir. Aktif politikada işadamının yerinin olmadığını, politikaya girmesi durumunda Koç Grubu'nun, dolayısıyla işadamlığının, devam ettirilemeyeceğini sürekli vurgulamaktadır. "O zaman politikaya atılsaydım, bugünkü Koç Müessesesi kurulamayacaktı" (Koç, 1973: 135).

Demokrat Parti döneminde gelişen şartlar Koç'un, aktif olmasa da, CHP içinde kalmasını zorlaştırmış ve kendisine yönelik baskılar artmıştır. Anıların belki de en kasvetli satırları bu bölümde yer almaktadır. Sonuçta işlerinin devamlılığını sağlamak adına, herhangi mantıklı bir sebep bulamamasına rağmen, $\mathrm{CHP}^{\prime}$ den istifa etmesi ve tarafsız kalması yönündeki baskılara dayanamamıştır. Bu durum işadamının siyaset kurumuyla bağlarının hem sıkı hem de zayıf olması gerektiğini açıkça göstermesi nedeniyle oldukça önemlidir. Gelecekte kuruluşuna öncülük edeceği TÜSİAD gibi kurumların kurulma gayesi, kanımca, işadamını siyaset kurumuyla ilgili işlerde savunmasız bırakmamak ve sürekliliğin sağlanmasıdır. Bilindiği gibi kuruluş aşamasında, Koç'un deyimiyle "fikir üreten bir fabrika" olarak nitelenen TÜSİAD (Berker ve Uras, 2009), günümüzde toplumsal inşa sürecinin önemli bir aktörü olma rolünü üstlenmiştir (Türk, 2009; Gölbaşı, 2007). "Tarafsız vatandaşlar da önceleri CHP'den büyük çıkarlar elde ettiğimi, doymadığımı, bu defa da daha çok çıkar sağlamak, vurgun yapmak için DP'ye girdiğimi sanacaklar ve benim karaktersiz bir adam olduğuma hükmedeceklerdir" (Koç, 1973: 143).

Bir tür aşk/nefret ilişkisine benzetebileceğimiz bu durum Buğra (2006: 138)'nın devletin belirsizlik yaratan müdahalelerini Türkiye'deki işadamları için en önemli zorluk olarak niteleme yönündeki savıyla da güçlü bir şekilde örtüşmektedir.

\section{3. 3. Holdingleşme}

Türkiye'deki tipik büyük iş birimi holding şeklinde örgütlenmiş çok dalda faaliyet gösteren şirketlerdir
(Buğra, 2006: 241). Koç için en önemli amaç sahip olduğu, kurduğu ve geliştirdiği işletmelerin sürekliliklerinin sağlanmasıdır. Koç bu konuda oldukça yoğun çaba göstermiştir. Süreklilik konusunda endişelenme sebeplerinin başında aile işletmelerinin kısa ömürlü olduğuna ilişkin inancı gelmektedir. Bu inancın en önemli destekleyicisi olarak yıllar içinde aile bağlarının zayıflaması ve işe gereken önemim verilmemesi yatmaktadır.

Koç kurduğu işletmelerin devamlılığını öncelikle vatanseverlik ve memlekete hizmet gibi daha üst normatif bağlantılar kurarak meşrulaştırmaktadır. Kültürel yapının kişisel çıkar çatışmaları doğurmaya oldukça yatkın olduğunu ve bu nedenle işletmelerin yetkin olmayan kişilerin yönetiminde yok olup gideceğini düşünmektedir. Tüm bu sorunları çözebilmek için iş arkadaşları, alan uzmanları, iş yaptığı yabancı işletmelerin temsilcileriyle görüş alış-verişinde bulunmakta ve sonuçta holding adında yeni bir örgütsel formun uyarlanarak, sahip olduğu işletmelerin holdingin katılımıyla yönetilmesinin uygun olacağı görüşüne varmaktadır. Bir başka ifadeyle, holding formunun Türkiye'deki tasarımı ve gelişiminde Vehbi Koç'un giriştiği kurumsal işlerin önemli bir yeri vardır. "Bu düşünce ile ilk aşamada topluluğun, yurda mal olmuş büyük şirketlerinin sürekliliklerini sağlamak için bunları gerçek anonim şirketler halinde geliştirmekle beraber, bir Holding şirketi çevresinde toplamak ve Holding'in bir kısım hisselerini, ailenin şahsi tesirinde kalmayacak bir Vakfa mal etmek bana en çıkar yol gözükmüştü..."(Koç, 1973: 101).

Holdingleşme Koç'un beklediği sonuçlara erişilmesini sağlamış mıdır? Holding benzeri iş grupları üzerine yapılan bir çalışmada Türkiye'de iş grubu bünyesinde faaliyet göstermenin fayda ve maliyet açısından önemli bir farklılık yaratmadığına vurgu yapılmaktadır (Khanna ve Rivkin, 2001: 61). Buğra (2006: 285) ise faaliyetleri ne kadar genişlemiş ve çeşitlenmiş olsa da Türk holding şirketlerini kurucu ailenin güdümünde ve sahipliğinde olan birimler olarak nitelendirmektedir. Bu yoruma göre Koç işadamı kurumunun holdingleşme aracılığıyla sürdürülebilirliğini sağlamış fakat yönetimin anonimleşmesi hedefini gerçekleştirememiştir.

Peki, Koç'un holdingleşme konusunda giriştiği kurumsal işlerin günümüzdeki etkileri sürmekte midir? Özen ve Yeloğlu (2006: 75) tarafından holding kimliğine ilişkin olarak yapılan genel bir değerlendirmede holding kavramının pragmatik meşruiyetini koruduğu fakat merkez-çevre çekişmesinde, kendisini çevreden soyutlamak isteyen örgütler açısından normatif kabul edilirliğinin azalma eğiliminde olduğu belirlenmiştir. Özetlemek gerekirse, holding formu cismen 
varlığını sürdürse de ismen popülaritesini yitirmiş bir kavram olarak nitelendirilebilir.

\section{3. 4. Vakıflaşma}

Vatanseverliğin ve dışsal kendilik kontrolünün doğal bir sonucu olarak, işadamı gelirinin belli bir kısmını hayır işlerinde kullanmalıdır şeklinde bir görüş Koç'un vakıflaşma serüveninin temel çıkış noktasıdır. Vakıf ayrıca kurulan holdingin önemli bir hissedarı olarak, holdingin yönetiminde aile etkisini azaltabilecek bir güç olarak da nitelendirilmektedir. "Hayatımda elde edebildiğim başarıyı Allaha, yurduma, değerli çalışma arkadaşlarımın işbirliğine ve çalışma sevgime borçluydum... [Amacım]sosyal hizmet ve bağışlarımızı kurumlaştırmak ve böylece bunların benden sonra da sürekliliğini sağlamaktı. Bu ikinci amacım Vehbi Koç Vakfı'nı kurduğum zaman gerçekleşti" (Koç,1973:127).

Koç'a göre işadamı toplumun gözünde olumlu bir yer edinmelidir. Bunun yolu da hayır işlerine vakit ve sermaye ayırmaktan geçmektedir. Vakıf ve holding arasında kurulacak karşılıklı etkileşim hem kurumsal sosyal sorumluluk çabalarını rasyonelleştirecek hem de holding yönetiminde aile etkisini azaltabilecektir. Bu şekilde işlerin ve işadamının varlığı daha güçlü bir şekilde sürekli kılınacaktır.

Koç anılarının birçok yerinde yurtdışında ziyaret ettiği köklü ortaklarının vakıflarına atıf yapmakta, özellikle de Ford Vakfı üzerinde durmaktadır. Bir başka ifadeyle, Koç'un zihninde tasarladığı vakıf kavramı daha çok Ford Vakfı benzeri kuruluşları nitelemek için kullanılmaktadır. Bu modelde vakıflar kurumsal hayırseverlik amacıyla örgütlenmiş liberal örgütler olarak betimlenmektedir (Anhier, 2001: 27). Türkiye bağlamında ise vakıf "Islam ve özellikle Türk dünyasında 8. Yüzyılın ortalarından 19. Yüzyılın sonlarına kadar sosyal, kültürel ve ekonomik alanlarda yoğun bir şekilde faaliyet göstermiş sosyal, siyasal ve dini kuruluşlar" olarak tanımlanmaktadır (Yediyıldız, 1996). Koç'un giriştiği kurumsal işlerin sonucunda ortaya çıkan vakıf türü, Fransız antropolog Claude Lévi-Strauss'un deyimiyle, kendi kültürel, bilişsel ve deneyimsel repertuarında var olan elemanları da kapsayan bir tür brikolaj olarak nitelendirilebilir (Duymedjian ve Rüling, 2010:137). Sonuçta, Koç'un vakıflaşma çabaları Türkiye'de devlet desteğiyle kurulan holdinglerin hayırseverlik fonksiyonlarını yerine getirmede önemli işlevler üstlenmiş ve kurumsal sosyal sorumluluk çabalarının ilk örneğini oluşturmuştur (Alakavular vd., 2009:119).

\section{3. 5. Mitleştirme}

Bilimsel kavramlar disiplinler arası yolculukları sırasında, belli bir disiplinden diğerine aktarılırken, tam olarak değil de alana uygun olarak seçilmiş kavramsal bir paket olarak aktarılmaktadırlar. Böyle bir durum kültür kavramının antropolojiden yönetim ve organizasyon alanına geçişi içinde söz konusudur (Meek, 1988). Meek (1988: 467)'e göre semboller aktörün anlam kümesiyle içinde bulunduğu örgütün diğer sosyal boyutları arasında karşılıklı etkileşim yaratan örgüt kültürü bileşenleridir. Belli bir kültürün, bir başka ifadeyle değerler bütünün, yayılımı ve sürdürülmesi için kullanılan önemli sembollerden birisi de mitlerdir. Koç işadamı kimliğini sürekli kılmak adına sahip olduğu ve gelecekte de korunmasını beklediği değerleri mitleştirmektedir. Örneğin Koç'un anılarının çeşitli bölümlerinde Ankaralı olma vurgusuna rastlanmaktadır. "Ankaralıyım. Aile şeceremden anlaşıldığına göre ana tarafindan 600, baba tarafindan da 250 yıllık Ankaralı bir aileden geliyorum" (Koç, 1973: 8).

Mitler yoluyla oluşturulan öykü nesiller arası bağları kuvvetlendirmekte ve öne çıkartılan değerlerin geleceğe aktarılma olasılığını artırmaktadır (Meek, 1988: 468). Bir başka deyişle, mitleştirmenin temel işlevi mitleştirilen olgunun geçerli ve sürdürülebilir kılınmasıdır (Halliday, 2008: 46). Koç'un tarihsel kökenini araştırtması ve sonuç olarak kendinin ve eşinin Hacı Bayram-ı Veli Hazretleri'nin 19'uncu kuşak torunu olduğunu kanıtlama çabası, süreklilik adına mitleştirmenin çarpıcı bir örneği olarak yorumlanabilir.

\section{SONUÇ VE ÖNERILER}

Giriş bölümünde çalışma kapsamında "Peki, kimdir bu işadamı, ne iş yapar, nasıl çalışır, neye önem verir?" sorusuna cevap arandığı belirtilmiştir. Bu amaçla Vehbi Koç'un Hayat Hikâyem başlıklı eserindeki kurumsal işler analiz edilmiş ve Vehbi Koç özelinde işadamı kavramını betimleyen bir portreye ulaşılmıştır.

İşadamı kavramını yapılandıran bir aktör olarak Koç, öncelikle alanda geçerli olan işadamı kavramını yıkmaya gayret etmiş, daha sonra bağlama özel bir işadamı kavramı oluşturmaya girişmiş ve devam eden süreçte de bu kavramın sürdürülmesi amacıyla çalışmalarına devam etmiş̧tir.

Sonuçları daha detaylı bir şekilde irdelediğimizde Türkiye'de faaliyet gösteren işadamının öncelikle toplumda yaygın bir şekilde geçerli olan işadamı kimliğiyle gayrimüslimliğin arasındaki bağı zayıflatarak yıkan bir aktör olduğu görülecektir. İşadamı iş dünyasındaki gayrimüslim tekelini yıkmakta fakat onların bilgi birikiminden yararlanmaya önem vermektedir. Işadamı kendi ticari çıkarları için çalışmaz, iş adamı aslında ülkenin ve toplumun refahı için çalışan bir aracıdır. Işadamı girişimlerine öncelikle ticaretle başlamalı, işlerini büyüterek mal üretimine geçmelidir. İşlerin gelişimi olumlu bir eğilim gösterirse işadamı hizmet sektörüne açılmalı 
ve bu aşamada ilk olarak turizm işinde şansını denemelidir. İşadamı sahip olduğu ticaret kapasitesini (mağazacılık) hiçbir zaman elden bırakmamalı, bunu kötü zamanlar için kullanılacak bir tampon olarak nitelendirmelidir. İsadamı çevresindekilerin tecrübelerinden öğrenmeli, bu kişileri güvenilir kılmak adına işlerine ortak etmeli veya bu kişilerle akrabalık ilişkileri geliştirme yoluna gitmelidir. İşadamı kendi ismine önem vermeli bunun işadamı kavramının oldukça önemli imgesel bir bileşeni olduğunu unutmamalıdır. Türkiye gibi siyasi ve ekonomik belirsizliklerin yoğun yaşandığı bir ortamda yaratılan işadamı kimliğinin sürdürülmesi kolay değildir. İşadamı işlerini olabildiğince çeşitlendirerek belirsizlik kaynaklı riskten kaçınmalıdır. İşadamı yaptığı işlerin büyük bir bölümünde devletle oldukça sıkı ilişkiler içinde olmalı fakat bu bağları her an koparabilecek esnekliği de bünyesinde barındırmalıdır. İşadamı çeşitlenen işlerini holding bünyesinde merkezileştirerek yönetmeli, hizmet adamlığını vakıflar aracılığıyla yürütmeli ve eğer şartlar uygun olursa kendisi ve ailesine ilişkin çeşitli efsanelerin üretimini ve yayılımını sağlayarak bulunduğu konumu mistik ögelerle desteklemelidir.

Yukarıda sonuçlarına değinilen çalışmanın eleştiriye açık yönleri de mevcuttur. Çalışma kapsamında yürütülen analiz sürecinde kodlamanın yalnızca yazar tarafında yapılması ve sadece Vehbi Koç tarafından kaleme alınan anıların analiz edilmesi eleştiri konusu olabilir. Daha sonraki araştırmalarda bu çalışma kapsamında betimlenen işadamı kavramının nicel medya analizleri aracılığıyla sorgulanması kavramsal geçerliliğin güçlendirilmesine önemli katkı yapacaktır. Çalışma kapsamında Vehbi Koç'un 1920-1970 yılları arasındaki 50 yıllık kariyeri analiz edilmiştir. Bu analiz 1980 öncesinin işadamı karakterini ortaya koymak açısından oldukça önemlidir. Fakat kavramın 1980 sonrası dönemde işadamlığı kariyerine başlayan ve günümüzde işlerini sürdüren işadamlarının yürüttükleri kurumsal işlerin incelenmesiyle daha bütüncül bir yapıya bürüneceği unutulmamalıdır. 


\section{SON NOTLAR}

${ }^{1}$ Çalışma kapsamında cinsiyet-bağımsız bir kavram olması açısından işadamı yerine iş insanı kavramı tercih edilebilirdi. Fakat gerek elde edilen veriler gerekse de dönemin sosyokültürel yapısı işadamı kavramının özellikle kullanılması gerektiğine işaret etmektedir. İş insanı ve işkadını kavramlarına ilişkin yapılan betimlemelerde ise feminist kuram ve eleştirel kuram benzeri kavramsal çerçevelerin analiz sürecine dâhil edilmesi önemli bir gerekliliktir.

${ }^{2}$ Anlatımda akıcılık sağlamak adına Vehbi Koç yerine bazı durumlarda sadece soyadı kullanılmıştır.

${ }^{3}$ Bu eser yazarın 1994 yılında SUNY Press tarafindan yayınlanan State and Business in Modern Turkey: Com- parative Study başlıklı eserinin 1995 yılında İletişim Yayınları tarafından Türkçe’ye tercüme edilen 2006 tarihli 5. baskısıdır.

${ }^{4} \mathrm{Bu}$ eser yazarın 1970 yılında Cem Yayınevi tarafından yayınlanan aynı adlı eserinin 2014 yılında Türkiye İş Bankası Kültür Yayınları tarafından yayınlanan 23. baskısıdır.

*Bu çalışma İstanbul Şehir Üniversitesi, İşletme ve Yönetim Bilimleri Fakültesi tarafından 7-8 Şubat 2014 tarihleri arasında düzenlenen 5. Örgüt Kuramı Çalıştayı'nda yer alan "Bu Topraklarda İşadamı Olmak" başlıklı bildirinin geliştirilerek güncellenmiş halidir.

\section{KAYNAKLAR}

Ahmadjian, C.L. ve Robinson, P. (2001) "Safety in Numbers : Downsizing and the Deinstitutionalization of Pernnanent Employment in Japan" Administrative Science Quarterly, 46:622-654.

Alakavuklar, O.N., Kılıçaslan, S. ve Öztürk, E.B. (2009) "Türkiye'de hayırseverlikten Kurumsal Sosyal Sorumluluğa Geçiş: Bir Kurumsal Değişim Öyküsü” Yönetim Araştırmaları Dergisi, 9(2):103-143.

Albert, S. ve Whetten, D.A. (1985) “Organizational Identity" Research in Organizational Behavior, Cummings et al. (eds) Greenwich, CT: JAI Press.

Aldemir, C.M., Arbak, Y. ve Özmen Timurcanday, Ö.N. (2003) “Türkiye'de İşgörme Anlayışı: Tanımı ve Boyutları” Yönetim Araştırmaları Dergisi, 3(1):5-28.

Anhier, H.K. (2001) "Foundations in Europe: A Comparative Perspective" Civil Society Working Paper Series, No:18.

Ashforth, B.E. ve Gibbs, B.W. (1990) "The Doubleedge of Organizational Legitimation" Organization Science, 1(2):177-194.

Barley, S.R. (1986) “Technology As An Occasion For Structuring: Evidence From Observations of CT Scanners and the Social Order of Radiology Departments" Administrative Science Quarterly, 31:78-108.

Battilana, J. ve D’Aunno, T. (2009) "Institutional work and the paradox of embedded agency" Lawrence et al (eds.) Institutional work: Actors and Agency In Institutional Studies of Organization, Cambridge, University of Cambridge Press.

Berger, P.L. ve Luckmann, T. (1966) The Social Construction of Reality: A Treatise in the Sociology of Knowledge, Hammondsworth, Penguin Books.
Berker, F. ve Uras, G. (2009) Fikir Üreten Fabrika: TÜSİAD’n İlk On Yilı 1970-1980, İstanbul, Doğan Kitap.

Berkman, Ü. ve Özen, Ş. (2007) “Turkish Business System and Managerial Culture: State-Dependency and Paternalism in Transition" Davel et al. (eds), Gestion en Contexte Interculturel: Approches, Problématiques, Pratiques Et Plongées. (Chapter VI.4), Québec: Presse de l'Université Laval et TÉLUQ/UQAM.

Buğra, A. (2006) Devlet ve İsadamlar, İstanbul, İletişim Yayınları.

Cem, İ. (2014) Türkiye’de Geri Kalmışlı̆̆ın Tarihi, 23. Baskı, İstanbul, Türkiye İş Bankası Kültür Yayınları.

Çolpan, A.M. ve Hikino, T. (2008) “Türkiye'nin Büyük Şirketler Kesiminde İşletme Gruplarının İktisadi Rolü ve Çeşitlendirme Stratejileri” Yönetim Araştırmaları Dergisi, 8(1-2): 23-58.

DiMaggio, P.J. ve Powell, W.W. (1983) “The Iron Cage Revisited: Institutional Isomorphism and Collective Rationality in Organizational Fields" American Sociological Review, 48:147-160.

DiMaggio, P.J. (1988) "Interest and Agency in İnstitutional Theory”, Zucker, L.G. (ed.) Institutional patterns and Organizations: Culture and Environment, Cambridge, Ballinger.

Duymedjian, R. ve Rüling, C.C. (2010) “Towards a Foundation of Bricolage in Organization and Management Theory" Organization Studies, 31(2):133-151.

Dündar, C. (2008) Özel Arşivinden Belgeler ve Anılarıyla Vehbi Koç: 1961-1976, İstanbul, Yapı Kredi Yayınları.

Dündar, C. (2006) Özel Arşivinden Belgeler ve Anılarıyla Vehbi Koç, İstanbul, Doğan Kitap. 
Eisenstadt, S.N. (1980) "Cultural Orientations, Institutional Entrepreneurs, and Social Change: Comparative Analysis of Traditional Civiliations" American Journal of Sociology, 85:840-869.

Emirbayer, M. ve Mische, A. (1998) "What Is Agency?" American Journal of Sociology, 103(4):962-1023.

Glaser, B.G. ve Strauss, A (1967) The Discovery of Grounded Theory, Chicago, Aldine.

Glaser, B.G. (1992) Basics of Grounded Theory Analysis, Mill Valley, Sociology Press.

Glynn, M.A. ve Abzug, R. (2002) "Institutionalizing Identity: Symbolic Isomorphism and Organizational Names" Academy of Management Journal, 45(1):267-280.

Gökşen, N. S. ve Üsdiken B. (2001) "Uniformity and Diversity in Turkish Business Groups: Effects of Scale and Time of Founding" British Journal of Management, 12(4):325-340.

Gölbaşı, Ş. (2007) “TÜSİAD’n Söylemleri Araciliğzyla Toplumu İnşa Girişimlerinin 24 Ocak Kararlar ve İzleyen Süreç Bağlamında Eleştirel Bir İncelemesi" Yayımlanmamış Doktora Tezi, Antalya, Akdeniz Üniversitesi, Sosyal Bilimler Enstitüsü.

Greenwood, R. ve Hinnings, C.R. (1996) "Understanding Radical Organizatonal Change: Bringing Togather the Old and the New Institutionalism" Academy of Management Review, 21:1022-154.

Greenwood, R., Oliver, C., Sahlin, K. ve Suddaby, R. (2008) Sage Handbook of Organizational Institutionalism, London, Sage Publucations.

Hughes, E.C. (1936) "The Ecological Aspect of Institutions" American Sociological Review, 1:180-189.

Jepperson, R.L. (1991) "Institutions, Institutional Effects and Institutionalism" Powell ety al (eds), The New Institutionalism in Organizational Analysis. Chicago, University of Chicago Press.

Khanna, T. ve Rivkin, J.W. (2001) "Estimating the Performance Effects of Business Gruops" Strategic Management Journal, 22(1):45-74.

Kıraç, C. (1996) Anılarmmla Patronum Vehbi Koç, İstanbul, AD Yayıncilı.

Koç, V. (1973) Hayat Hikâyem, İstanbul, APA Ofset Basımevi.

Koç, V. (1984) Hatıralarım, Görüşlerim, Ögüülerim Vehbi Koç (1973-1987), İstanbul, Vehbi Koç Vakfi.

Länsisalmi, H., Peiró, J. ve Kivimäki, M. (2004) "Grounded Theory in Organizational Research" Gillian et al.(eds), Essential Guide to Qualitative Methods in Organization Research, London, Sage Publucations.
Lawrence, T.B. ve Suddaby, R. (2006) "Institutions and Institutional Work", Clegg et al. (eds.) The Sage Handbook of Organization Studies,London, Sage Publucations.

Lawrence, T.B., Leca, B., ve Zilber, T.B. (2013) "Institutional Work: Current Research, New Directions and Overlooked Issues" Organization Studies, 34(8): 10231033.

Lawrence, T., Suddaby, R. ve Leca, B. (2010) "Institutional Work: Refocusing Institutional Studies of Organization" Journal of Management Inquiry, 20(1):52-58.

Lawrence, T., Suddaby, R. ve Leca, B. (2009) Institutional Work: Actors and Agency in Institutional Studies of Organizations Lawrence et al.(eds.) New York, Cambridge University Press.

Lawrence, TB, Hardy, C. ve Phillips, N. (2002) "Institutional Effects of Interorganizational Collaboration: The Emergence of Proto-institutions" Academy of Management Journal, 45(1): 281-290.

Locke, K.D. (2001) Grounded Theory in Management Research, London, Sage Publucations.

Meek, V.L. (1988) "Organizational Culture: Origins and Weaknesses" Organization Studies, 9(4): 453-473.

Meyer, J.W. ve Rowan, B. (1977) "Institutionalized Organizations: Formal Structure As Myth and Ceremony" American Journal of Sociology, 83:340-363.

Myers, M.D. (2009) Qualitative Research in Business $\&$ Management, London, Sage Publucations

Oliver, C. (1992) "The Antecedents of the Institutionalisation" Organization Studies, 13:563-588.

Oxford Dictionaries (2014) http://www.oxforddictionaries.com/definition/english/businessman, (09.01.2014).

Özen, Ş. ve Yeloğlu, H.O. (2006) "Bir Örgüt Kimliği Olarak "Holding" Adının İnşası ve Aşınması: Eşanlı Kurumsallaşma ve Çözülme Üzerine Bir Model Önerisi" Yönetim Araştırmaları Dergisi, 6(1-2):45-84.

Patton, M.Q. (2002) Qualitative Research \& Evaluation Methods 3rd. Edition, Thousand Oaks, Sage Publucations

Phillips, N. ve Lawrence, T.B. (2012) “The Turn to Work in Organization and Management Theory: Some Implications for Strategic Organization" Strategic Organization, 10(3):223-230.

Sargut, A.S. (2001) Kültürler Arası Farklılaşma ve Yönetim 2. Bask1, Ankara,İmge.

Scott, W.R. (2008) Institutions and Organizations: Ideas and Interests, Thousand Oaks, Sage Publucations. 
Strauss, A.L. ve Corbin, J. (1990) Basics of Qualitative Research: Grounded Theory Procedures and Techniques, Thousand Oaks, Sage Publucations.

Suddaby, R. (2006) "From the Editors: What Grounded Theory Is Not" Academy of Management Journal, 49(4):633-642.

Türk, E. (2009) TÜSİAD Patronlar Kulübü, İstanbul, Alfa.

Türk Dil Kurumu Sözlüğü (2014) http://www.tdk. gov.tr/, (10.01.2014).

Yediyıldız, B. (1996) "Place of the waqf in Turkish Cultural System" Habitat II Kongresinde Sunulmuş Bildiri, 12 Nisan 1996: İstanbul. 23.01.2014 tarihinde http://yunus.hacettepe.edu.tr/ -yyildiz/placeofthewaqf. htm adresinden erişilmiştir.

Whitley, R. (2000). Divergent Capitalisms: The Social Structuring and Change of Business Systems, Oxford, Oxford University Press. 